\title{
Amiloride-Insensitive Salt Taste Is Mediated by Two Populations of Type III Taste Cells with Distinct Transduction Mechanisms
}

\author{
Brian C. Lewandowski, Sunil K. Sukumaran, Robert F. Margolskee, and ๑Alexander A. Bachmanov \\ Monell Chemical Senses Center, Philadelphia, Pennsylvania 19104
}

Responses in the amiloride-insensitive (AI) pathway, one of the two pathways mediating salty taste in mammals, are modulated by the size of the anion of a salt. This "anion effect" has been hypothesized to result from inhibitory transepithelial potentials (TPs) generated across the lingual epithelium as cations permeate through tight junctions and leave their larger and less permeable anions behind (Ye et al., 1991). We tested directly the necessity of TPs for the anion effect by measuring responses to $\mathrm{NaCl}$ and Na-gluconate (small and large anion sodium salts, respectively) in isolated taste cells from mouse circumvallate papillae. Using calcium imaging, we identified AI salt-responsive type III taste cells and demonstrated that they compose a subpopulation of acid-responsive taste cells. Even in the absence of TPs, many (66\%) AI salt-responsive type III taste cells still exhibited the anion effect, demonstrating that some component of the transduction machinery for salty taste in type III cells is sensitive to anion size. We hypothesized that osmotic responses could explain why a minority of type III cells (34\%) had AI salt responses but lacked anion sensitivity. All AI type III cells had osmotic responses to cellobiose, which were significantly modulated by extracellular sodium concentration, suggesting the presence of a sodium-conducting osmotically sensitive ion channel. However, these responses were significantly larger in AI type III cells that did not exhibit the anion effect. These findings indicate that multiple mechanisms could underlie AI salt responses in type III taste cells, one of which may contribute to the anion effect.

Key words: amiloride; anion; osmolarity; salt; sour; taste

\section{Significance Statement}

Understanding the mechanisms underlying salty taste will help inform strategies to combat the health problems associated with $\mathrm{NaCl}$ overconsumption by humans. Of the two pathways underlying salty taste in mammals, the amiloride-insensitive (AI) pathway is the least understood. Using calcium imaging of isolated mouse taste cells, we identify two separate populations of AI salt-responsive type III taste cells distinguished by their sensitivity to anion size and show that these cells compose subpopulations of acid-responsive taste cells. We also find evidence that a sodium-conducting osmotically sensitive mechanism contributes to salt responses in type III taste cells. Our data not only provide new insights into the transduction mechanisms of AI salt taste but also have important implications for general theories of taste encoding.

\section{Introduction}

At least two pathways underlie salty taste in mammals. The amiloride-sensitive (AS) pathway responds selectively to sodium

Received July 31, 2015; revised Dec. 7, 2015; accepted Dec. 29, 2015.

Author contributions: B.C.L., R.F.M., and A.A.B. designed research; B.C.L. and S.K.S. performed research; B.C.L. and S.K.S. analyzed data; B.C.L., R.F.M., and A.A.B. wrote the paper.

Research reported in this publication was supported by National Institutes of Health (NIH) Grants DC012980 (B.C.L.), DC000882 (A.A.B.), DC03155 (R.F.M.), and DC014105 (R.F.M.). B.C.L. acknowledges support from NIH/ National Institute on Deafness and Other Communication Disorders (NIDCD) Postdoctoral Training Grant 5T32DC0014. Imaging was performed at the Monell Histology and Cellular Localization Core, which is supported in part by NIH/NIDCD Core Grant 1P30DC011735-01. We thank all members of the Margolskee laboratory for their input and Steven Luminais for his help with the coding of MATLAB scripts for processing calcium imaging data. We also thank Dr. Cailu Lin for his help with statistical tests for bimodal distributions.

The authors declare no competing financial interests. (and lithium) salts and is mediated by the epithelial sodium channel (Heck et al., 1984; Chandrashekar et al., 2010; Roper, 2015). The amiloride-insensitive (AI), or high-salt pathway, responds to a broad range of sodium and non-sodium salts (Ninomiya and Funakoshi, 1988; Halpern, 1998), yet the underlying receptor(s) remain unknown. TRPV1 receptor variants have been proposed as AI salt receptor candidates (Lyall et al., 2004); however, highsalt responses persist in mice lacking these channels, so their exact role in salt taste remains unclear (Ruiz et al., 2006; Treesukosol et

Correspondence should be addressed to Brian C. Lewandowski, 3500 Market Street, Philadelphia, PA 19146 E-mail: blewandowski@monell.org.

DOI:10.1523/JNEUROSCI.2947-15.2016

Copyright $\odot 2016$ the authors $\quad 0270-6474 / 16 / 361942-12 \$ 15.00 / 0$ 
al., 2007). AI salt responses have been reported in two distinct populations of taste bud cells: (1) a subpopulation of bitterresponsive type II taste cells; and (2) the polycystic kidney disease 2-like 1 (PKD2L1)-expressing type III taste cells critical for sour taste (Oka et al., 2013). Because of the prevalence of cell-to-cell communication in the taste bud (Roper, 2013), it is unclear to what degree sour and AI salt responses co-occur in type III taste cells.

Although the cation is typically considered the proximal stimulus for salty taste, responses in the AI salt pathway (but not the AS pathway) are significantly modulated by the anion. In the AI salt pathway, larger anion salts produce smaller responses, a phenomenon known as the "anion effect" (Beidler, 1967; Elliott and Simon, 1990; Ye et al., 1991, 1993; Rehnberg et al., 1993; Kitada, 1995; Kitada et al., 1998). When the taste bud is exposed to a large anion salt, smaller cations diffuse through tight junctions at the taste pore, leaving their less permeable anions behind. This creates a transepithelial potential (TP) across the taste bud whose magnitude is correlated with the size of the anion of a salt (Ye et al., 1991, 1993). One theory to explain the anion effect hypothesizes that these TPs act as inhibitory field potentials, either directly inhibiting taste cell depolarization in response to salt stimuli or else inhibiting the diffusion of cations to the basolateral membrane of taste cells where the currently unidentified AI salt receptor(s) could be expressed (Elliott and Simon, 1990; Ye et al., 1991, 1993).

To gain insight into the nature of AI salt taste, we recorded calcium responses from AI salt-responsive taste cells in an isolated taste cell preparation. Recording from isolated taste cells removes any possible influence of TPs or cell-to-cell communication on taste cell responses. AI salt responses were observed in a subset of acid-responsive type III taste cells. A majority of isolated AI salt-responsive type III taste cells exhibited the anion effect, indicating that some component of the transduction machinery housed within these AI salt taste cells is either inhibited by larger anions or else requires smaller anions to function efficiently. We also found that a sodium-conducting osmotically sensitive channel may underlie salt responses in AI type III cells that do not exhibit the anion effect.

\section{Materials and Methods}

\section{Reagents and solutions}

Calcium-free Tyrode's solution was composed of the following (in mM): $140 \mathrm{NaCl}, 5 \mathrm{KCl}, 10 \mathrm{HEPES}, 10$ glucose, $1 \mathrm{Na}$-pyruvate, and $2 \mathrm{EGTA}, \mathrm{pH}$ 7.4. Low- $\mathrm{NaCl}$ Tyrode's solution, used as the bath solution during calcium imaging, was composed of the following (in mM): $30 \mathrm{NaCl}, 110$ $\mathrm{N}$-methyl-D-glucamine (NMDG)-Cl (Sigma), $5 \mathrm{KCl}, 4 \mathrm{CaCl}_{2}, 1 \mathrm{MgCl}_{2}$, 10 HEPES, 10 glucose, and $1 \mathrm{Na}$-pyruvate, $\mathrm{pH}$ 7.4. The $50 \mathrm{~mm} \mathrm{KCl}$ and 50 $\mathrm{mm}$ citric acid stimuli were dissolved in low- $\mathrm{NaCl}$ Tyrode's with an equimolar substitution of $\mathrm{KCl}$ or citric acid for NMDG. $\mathrm{NaCl}$ and $\mathrm{Na}-$ gluconate test solutions were made by completely replacing the $\mathrm{NaCl}$ and NMDG normally found in Tyrode's solution with the indicated concentration of $\mathrm{NaCl}$ and/or Na-gluconate. Other tastants and pharmacological agents were dissolved directly into the indicated buffer or stimulus. The $\mathrm{pH}$ of all solutions was adjusted to 7.4 using $\mathrm{NaOH}$ or $\mathrm{HCl}$, except for $50 \mathrm{~mm}$ citric acid, which was adjusted to $\mathrm{pH} 4$. Reagents were obtained from Thermo Fisher Scientific unless otherwise noted.

\section{Isolated taste cell preparation}

All experimental procedures were approved by the Monell Animal Care and Use Committee. Following National Institute of Health recommended procedures, adult male C57BL/6 mice (Charles River Laboratories) were killed by exposure to $\mathrm{CO}_{2}$, followed by cervical dislocation. The tongue was excised and washed briefly in cold DMEM (Thermo Fisher Scientific) before a protease mixture consisting of $1 \mathrm{mg} / \mathrm{ml}$ colla- genase, type IV (Worthington), $2 \mathrm{mg} / \mathrm{ml}$ dispase II (Sigma), and $1 \mathrm{mg} / \mathrm{ml}$ trypsin inhibitor, soybean purified (Worthington) dissolved in calciumfree Tyrode's solution was injected under the lingual epithelium. After a $12 \mathrm{~min}$ incubation at $37^{\circ} \mathrm{C}$, the lingual epithelium was peeled and then washed with and incubated in $\mathrm{Ca}^{2+}$-free Tyrode's solution for $30 \mathrm{~min}$ at room temperature. Isolated taste cells from the circumvallate papillae (CV) were collected using pulled glass pipettes (DMZ-Universal Puller; Zeitz Instruments) and expelled onto Cell-Tak (BD Biosciences)-coated coverslips. Immediately before cell collection, the $\mathrm{Ca}^{2+}$-free Tyrode's solution was replaced with DMEM. Cells were allowed at least $60 \mathrm{~min}$ to settle onto the coverslips before functional imaging. Taste cells from CV taste buds were used in this study because they contain a higher number of type III taste cells relative to fungiform taste buds (Vandenbeuch et al., 2008) and they do not exhibit AS salt responses (Formaker and Hill, 1991; Kitada et al., 1998; Ninomiya, 1998).

\section{Calcium imaging}

Isolated taste cells were transferred to an imaging chamber (RC-26; Warner Instruments) and loaded with fura-2 AM (6.5 $\mu \mathrm{M}$; Invitrogen) containing the dispersing agent Pluronic F-127 (Invitrogen) for $30 \mathrm{~min}$ at $37^{\circ} \mathrm{C}$. Calcium imaging was conducted using an Olympus BX51-WI upright fixed-stage microscope (Olympus America) and associated MetaFluor for Olympus control software in conjunction with a Hamamatsu C9100 digital camera (Hamamatsu Photonics) and Sutter Instruments Lambda 10-2 optical control system. During experiments, cells were kept under constant perfusion. Stimuli were perfused inline using a twoposition microelectric actuator (Valco Instruments). The time from the beginning of stimulus exposure to the conclusion of stimulus washout was $\sim 20 \mathrm{~s}$; this includes $\sim 5 \mathrm{~s}$ for the stimulus to replace the bath solution, $10 \mathrm{~s}$ during which the cells were exposed to the full concentration of a stimulus, and $\sim 5 \mathrm{~s}$ for the bath solution to wash out the stimulus. Cells were given at least $8 \mathrm{~min}$ of recovery time between stimuli. Fura- $2 \mathrm{cal}-$ cium signals were measured at a capture rate of $2 \mathrm{~s}$ during stimulus presentations, with excitation wavelengths of 340 and $380 \mathrm{~nm}$ and emission measured at $510 \mathrm{~nm}$. To reduce cellular exposure to ultraviolet light and photobleaching of the fura-2 fluorophore, the sampling rate was reduced $(4-8 \mathrm{~s})$ during the prolonged and approximately linear recovery phase of calcium responses and further reduced (10-45 s) during baseline periods between stimuli. Calcium levels were estimated using the ratio of fluorescent intensities at $340 / 380 \mathrm{~nm}$. In experiments characterizing responses in putative AI type III taste cells, cell responsiveness was monitored by occasional application of a $250 \mathrm{~mm} \mathrm{NaCl}$ or $250 \mathrm{~mm} \mathrm{NaCl}$ plus $100 \mu \mathrm{M}$ amiloride stimulus; only data from stimuli presented when cells were showing robust and consistent $\mathrm{NaCl}$ responses are included. Data from cells with baseline calcium levels that fluctuated by $>5 \%$ of their peak magnitude response to $250 \mathrm{~mm} \mathrm{NaCl}$ were discarded. Peak magnitude response was defined as the maximum $F_{340 / 380 \mathrm{~nm}}$ value after stimulus presentation minus the average baseline value in the $120 \mathrm{~s}$ before stimulus presentation. Occasionally, cells would experience small shifts in steady-state intracellular calcium levels after stimulation (usually after the first stimulus presented). Data from stimuli presented after a change in resting calcium levels of $>5 \%$ of the cells peak magnitude response to $250 \mathrm{~mm} \mathrm{NaCl}$ were discarded. For the bitter-responsive cells and sour-only responsive cells that did not respond to $250 \mathrm{~mm} \mathrm{NaCl}$, we used the peak magnitude of the response to the bitter tastant mix $(10 \mathrm{~mm}$ denatonium plus $0.5 \mathrm{~mm}$ cycloheximide) or the $50 \mathrm{~mm}$ citric acid stimulus, respectively.

In initial experiments, putative AI salt-responsive type III cells were identified based on responses to $250 \mathrm{~mm} \mathrm{NaCl}, 250 \mathrm{~mm} \mathrm{NaCl}$ plus $100 \mu \mathrm{M}$ amiloride, and $50 \mathrm{~mm} \mathrm{KCl}$. All taste cells in these experiments that responded to $250 \mathrm{~mm} \mathrm{NaCl}$ also responded to $250 \mathrm{~mm} \mathrm{NaCl}$ plus $100 \mu \mathrm{M}$ amiloride and $50 \mathrm{~mm} \mathrm{KCl}$. Furthermore, all cells that responded to 250 $\mathrm{mm} \mathrm{NaCl}$ also responded to $50 \mathrm{~mm}$ citric acid, $\mathrm{pH} 4$, when tested (see Fig. 2). Thus, in subsequent experiments focused on the anion effect (see Fig. 3) and osmotic responses (see Fig. 4) in which larger numbers of stimuli needed to be tested, a response to $250 \mathrm{~mm} \mathrm{NaCl}$ and at least one of the stimuli mentioned above $(250 \mathrm{~mm} \mathrm{NaCl}$ plus $100 \mu \mathrm{M}$ amiloride, 50 $\mathrm{mm} \mathrm{KCl}$, or $50 \mathrm{~mm}$ citric acid, $\mathrm{pH}$ 4) was used as a minimal criteria for physiological identification of AI salt-responsive type III taste cells. 
Table 1. Primer sequences for taste cell marker genes used in RT-PCR

\begin{tabular}{|c|c|c|}
\hline RT- $P C R$ primer sequence & Annealing temperature & Product size \\
\hline $\begin{array}{l}\text { PLC } \beta 2 \\
\text { Forward, tacacccccacagatatgttcctt } \\
\text { Reverse, ggtcactctcggtgttcctaaaga }\end{array}$ & $60^{\circ} \mathrm{C}$ & 142 bp \\
\hline $\begin{array}{l}\text { GLAST } \\
\text { Forward, ctagagatcctgagcatcccatgt } \\
\text { Reverse, ttgatgcgattaaggtctgttcaa }\end{array}$ & $60^{\circ} \mathrm{C}$ & $157 \mathrm{bp}$ \\
\hline $\begin{array}{l}\text { SNAP25 } \\
\text { Forward, ttggctgaaactatgtgaaatgga } \\
\text { Reverse, atggtgattaacaagagccagacg }\end{array}$ & $60^{\circ} \mathrm{C}$ & 133 bp \\
\hline $\begin{array}{l}\text { NCAM } \\
\text { Forward, cattttctatggaacctcccatgt } \\
\text { Reverse, aaggtggtgttgatgtttcactca }\end{array}$ & $60^{\circ} \mathrm{C}$ & $164 \mathrm{bp}$ \\
\hline $\begin{array}{l}\text { PKD2L1 } \\
\text { Forward, gtggtgagattccaacagaggagt } \\
\text { Reverse, tcaggttttgtttgattccaggtt }\end{array}$ & $60^{\circ} \mathrm{C}$ & $147 \mathrm{bp}$ \\
\hline
\end{tabular}

Single-cell RT-PCR

Cells identified by calcium imaging were collected by aspiration using a microcapillary attached to a microinjection device (CellTram Oil, cata$\log \# 5176000$ 025; Eppendorf) positioned using a Sutter Instruments MP-285 motorized micromanipulator. Collected cells were expelled into PCR tubes containing $2 \mu \mathrm{l}$ of QuickExtract RNA Extraction Solution (catalog \#QER09015; Epicenter), immediately flash frozen in a mixture of dry ice and ethanol, and stored at $-80^{\circ} \mathrm{C}$. Single-cell RNA amplification was conducted using the TargetAmp 2-Round aRNA (antisense RNA) Amplification Kit 2.0 (catalog \#TAU2R51224; Epicenter) following the kit protocol with a modification: aRNA was purified after the first and second rounds of in vitro transcription using the RNA Clean \& Concentrator 5 kit (catalog \#R1015; Zymo Research). The aRNA was used for RNA-Sequencing library preparation using the NEBNext mRNA library prep master mix set for Illumina following the kit protocol with a modification: $500 \mathrm{ng}$ of aRNA was used as input, and RNA fragmentation was done for $2 \mathrm{~min}$ at $94^{\circ} \mathrm{C}$. The sequencing library was diluted 10 -fold, and $1 \mu \mathrm{l}$ was used as template for end-point PCR using previously established methods (Yee et al., 2011) with primer sequences detailed in Table 1.

\section{Calcium imaging data analysis}

Initial data analysis was conducted using custom scripts written in MATLAB (MathWorks). The magnitude of response to a given stimulus was quantified by comparing the average calcium signal $90 \mathrm{~s}$ after the onset of stimulus presentation to the average baseline signal in the $120 \mathrm{~s}$ before the onset of stimulus presentation $\left(\Delta F=F_{\text {response }}-F_{\text {baseline }}\right)$. Fluorescence is reported in arbitrary units (AUs). A larger window is used to calculate the average baseline signal to compensate for dynamic adjustments in capture rate during experiments (described above). Calcium signals for baseline and response periods were quantified using the average area under the curve as a metric. Average area under the curve was calculated using a trapezoidal approximation: $F_{\text {Avg }}=((b-a) / 2 n) \times$ $\left[f\left(x_{0}\right)+2 f\left(x_{1}\right)+\ldots+2 f\left(x_{n-1}\right)+f\left(x_{n}\right)\right]$, where $n$ is the number of data points between times $a$ and $b$. In analyses in which data are compared across cells, stimulus-induced responses in a given cell were normalized to the average magnitude of the $250 \mathrm{~mm} \mathrm{NaCl}$ response of that cell. An evoked response to a stimulus was considered significant if the calcium signal after stimulus presentation remained $>10$ SDs above the baseline average for $10 \mathrm{~s}$ consecutively. Statistical analyses to compare response magnitudes, time-to-peak measurements, and response durations were conducted using Student's $t$ tests, two-tailed. Paired Student's $t$ tests were used when possible. However, many cells could only be tested with a subset of the total stimuli. Statistical analyses for stimuli tested in only partially overlapping subsets of cells were conducted using two-sample Student's $t$ tests assuming unequal variance. When average values are reported, SEM is included.

Time-to-peak response was defined as the time from the onset of stimulus perfusion until the maximum value of the calcium response. Response duration was defined as the time from the onset of stimulus perfusion until the calcium response dropped below a threshold of $10 \%$ of the peak response to the stimulus (relative to baseline): Response duration threshold $=F_{\text {baseline }}+0.1 \times\left(F_{\text {peak response }}-F_{\text {baseline }}\right)$. Baseline values were calculated as described above. Cell response data for each stimulus were inspected visually for any artifacts that might interfere with peak response or duration measurements.

Average response plots. For each presentation of a given stimulus, data from $120 \mathrm{~s}$ before and $600 \mathrm{~s}$ after stimulus presentation were extracted and scaled by first subtracting the average baseline $F_{340 / 380}$ value (calculated from the $120 \mathrm{~s}$ before stimulus presentation) from each data point and then dividing all data points by the peak response value (measured from the $600 \mathrm{~s}$ after stimulus presentation). These scaled data for each stimulus were then binned to enable averaging across all stimulus presentations. Bin sizes were adjusted to reflect the average capture rate during different time periods surrounding stimulus presentation and the properties of the response being averaged. When multiple data points from a single stimulus presentation fell into the same bin, the average value was taken. Average response plots were then created by calculating the average \pm SEM value for each individual bin.

Test for unimodal versus bimodal distribution. To test whether data are better fit by a unimodal normal distribution or a bimodal normal distribution, we fit the data with a normal model (mean $\mu$ and variance $\partial^{2}$ ) and a mixture normal model (mean $\mu_{1}$ and variance $\partial_{1}^{2}$ and proportion $\pi$ for the first model; mean $\mu_{2}$ and variance $\partial_{2}^{2}$ and proportion $1-\pi$ for the second model). The normal model (unimodal distribution) was fit using the maximum likelihood method. The mixture normal model provides a flexible bimodal distribution and was fit by the expectationmaximization algorithm. For estimation of bimodal normal models, the variances of the two components were estimated separately because they may be unequal. The tests of fitting of both models were implemented by the publically available NOCOM program (Ott, 1992). Hypothesis testing ( $\mathrm{H} 0$, unimodal normal model vs $\mathrm{Ha}$, mixture normal model) was performed by comparing nested models using likelihood ratio tests to select a best-fitting model. In this study, results for bimodal models are based on mixture normal model distributions with unequal variances for two normal components, and $p$ values are based on a $\chi^{2}$ distribution with 6 df (McLachlan, 1987; Gutierrez et al., 1995).

\section{Results \\ Identification of salt-responsive AI taste cells in isolated taste cell preparations}

The major goal of these experiments was to test the hypothesis that the anion effect is caused by negative TPs generated across the taste bud by the differential permeability of tight junctions at the taste pore to anions and cations (Ye et al., 1991, 1993). To test this hypothesis, we used an isolated taste cell preparation of mouse CV taste cells to remove any influence of TPs on taste cell responses. Our first step was to confirm that we could reliably identify our target population of AI salt-responsive type III taste cells (hereafter abbreviated as AI type III taste cells). Using fura-2 functional calcium imaging, we identified cells that gave calcium responses to salt ( $250 \mathrm{mM} \mathrm{NaCl}$ ), did not exhibit amiloride inhibition ( $250 \mathrm{~mm} \mathrm{NaCl}$ plus $100 \mu \mathrm{M}$ amiloride), and responded to depolarization with $50 \mathrm{~mm} \mathrm{KCl} \mathrm{(a} \mathrm{physiological} \mathrm{identifier} \mathrm{of} \mathrm{type}$ III cells in isolated preparations; DeFazio et al., 2006; Fig. 1A,B). To prevent any potential desensitization of salt transduction pathways, the bath solution used during recording of isolated taste cell responses was a low- $\mathrm{NaCl}$ modification of Tyrode's solution, in which an equimolar substitution of NMDG-Cl for $\mathrm{NaCl}$ was used to bring the $\mathrm{NaCl}$ concentration down to $30 \mathrm{~mm}$. None of the taste cells we recorded from exhibited AS salt responses. This agrees with previous studies in mice that find no evidence of AS taste cells in CV taste buds (Chandrashekar et al., 2010) and no AS component to salt responses in the glossopharyngeal nerve that innervates the CV taste buds (Ninomiya, 1998). 
A
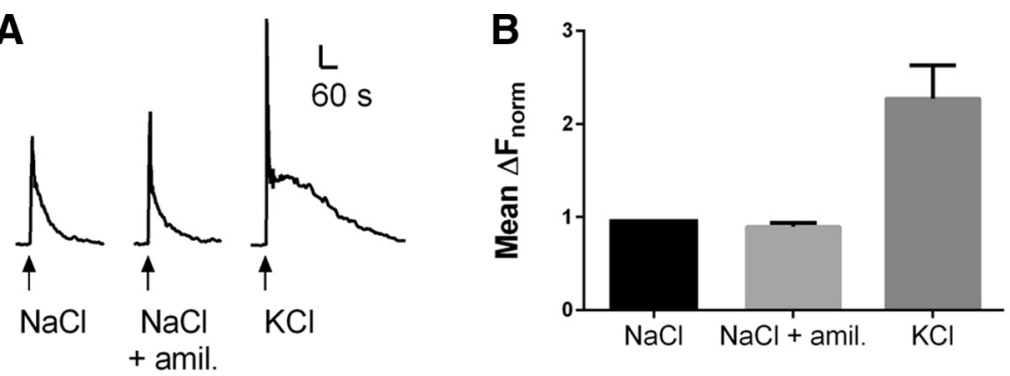

C

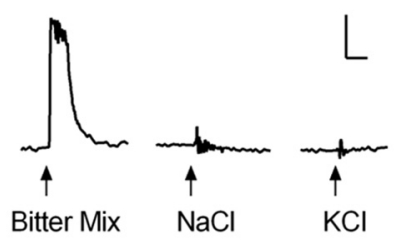

E

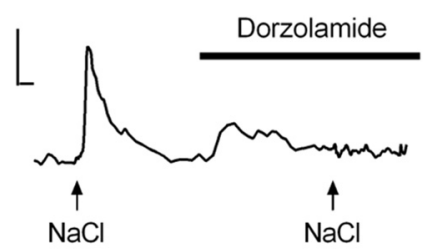

D

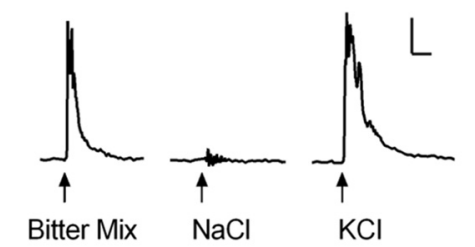

$\mathbf{F}$

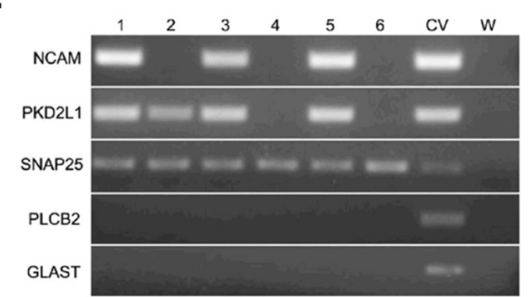

Figure 1. $\mathrm{Ca}^{2+}$ responses to taste stimuli and $\mathrm{KCl}$ depolarization in isolated CV taste cells can be used to reliably identify $\mathrm{Al}$ salt-responsive type III taste cells. A, An example of an isolated Al type III taste cell loaded with fura-2 AM responding with increases in $\left[\mathrm{Ca}^{2+}\right]_{\mathrm{i}}$ to $250 \mathrm{~mm} \mathrm{NaCl}, 250 \mathrm{~mm} \mathrm{NaCl}$ plus $100 \mu \mathrm{m}$ amiloride (amil.), and depolarization with $50 \mathrm{~mm} \mathrm{KCl}$. Black arrows indicate onset of stimulus presentation (duration $\sim 20$ s; see Materials and Methods). $\boldsymbol{B}$, Average \pm SEM normalized responses for $16 \mathrm{Al}$ type III taste cells identified by responses to $250 \mathrm{~mm} \mathrm{NaCl}, 250 \mathrm{~mm} \mathrm{NaCl}$ plus $100 \mu \mathrm{m}$ amiloride, and $50 \mathrm{~mm} \mathrm{KCl}$ depolarization. The average response of a cell to $250 \mathrm{~mm} \mathrm{NaCl}$ was used to normalize its responses to other stimuli (bar for $250 \mathrm{~mm} \mathrm{NaCl}$ is shown to aid visualization). C, D, Examples of isolated taste cells that responded to a bitter tastant mix (10 mm denatonium plus $0.5 \mathrm{~mm}$ cycloheximide) with $\mathrm{Ca}^{2+}$ transients. A minority of bitter-responsive cells responded to $50 \mathrm{~mm} \mathrm{KCl}(n=4 ; \boldsymbol{D})$, but most did not $(n=8 ; \boldsymbol{C}$ ). No bitter-responsive taste cells recorded in these experiments responded to $250 \mathrm{~mm} \mathrm{NaCl}$. $\boldsymbol{E}$, Exemplar data from an isolated Al type III taste cell showing inhibition of $\mathrm{Ca}^{2+}$ responses to $250 \mathrm{~mm} \mathrm{NaCl}$ after incubation with $200 \mu \mathrm{m}$ dorzolamide, a carbonic anhydrase inhibitor. Vertical scale bars in $\boldsymbol{A}, \boldsymbol{C}-\boldsymbol{E}: 0.1 F_{340 \mathrm{~nm} / 380 \mathrm{~nm}}$ in AUs. $\boldsymbol{F}$, Single-cell RT-PCR results from six isolated AI type III taste cells (lanes 1-6) identified based on responses to $250 \mathrm{~mm} \mathrm{NaCl}, 250 \mathrm{~mm} \mathrm{NaCl}$ plus $100 \mu \mathrm{m}$ amiloride, and $50 \mathrm{~mm} \mathrm{KCl}$. Expression of type III cell markers NCAM, PKD2L1, and SNAP25 was detected in the Al type III taste cells. No expression was seen for type II cell marker PLC $\beta 2$ and type I cell marker GLAST. CV, CDNA prepared from whole CV taste buds, was used as positive control. $W$, Reaction run using nuclease-free distilled water as negative control.

AI salt taste responses have been described in two distinct populations of taste cells: (1) the PKD2L1-expressing type III taste cells also known to include acid-responsive taste cells (Huang et al., 2006; Oka et al., 2013); and (2) a subpopulation of bitter-responsive type II taste cells (Oka et al., 2013). It might be expected that the latter population (bitter/salt-responsive type II cells) would respond to the same salt stimuli being used to physiologically identify AI type III taste cells. To determine whether we could distinguish between AI salt responses in type II versus type III taste cells, we used a bitter tastant mix (10 mM denatonium plus $0.5 \mathrm{~mm}$ cycloheximide) to identify bitter-responsive (type II) taste cells and then tested their responses to $250 \mathrm{~mm}$ $\mathrm{NaCl}$ and $50 \mathrm{~mm} \mathrm{KCl}$ (Fig. 1C,D). Of 12 bitter-responsive taste cells, four gave significant responses to $\mathrm{KCl}$, which agrees well with similar experiments in isolated taste cells (Hacker et al., 2008). However, no responses to $250 \mathrm{~mm} \mathrm{NaCl}$ were observed in any of the bitter-responsive taste cells. This would seem to contradict reports of $\mathrm{NaCl}$ and $\mathrm{KCl}$ responses in some bitter taste cells (Oka et al., 2013); however, bitter/salt-responsive taste cells are not well characterized, and it is possible that they require higher concentrations of $\mathrm{NaCl}$ to induce responses or they may be rare or absent in CV taste buds. It is also possible that some of these cells are bitterresponsive type III taste cells (Hacker et al., 2008). However, our results do suggest that responses to $250 \mathrm{~mm} \mathrm{NaCl}$ can be used to reliably distinguish between AI type III and AI type II taste cells isolated from CV taste buds. This conclusion is further supported by the ability of dorzolamide, a broad-spectrum carbonic anhydrase inhibitor, to inhibit salt responses in physiologically identified AI type III taste cells (Fig. 1E). Previous studies have shown that dorzolamide inhibits AI salt responses in type III but not type II taste cells (Oka et al., 2013).

As a final confirmation that our stimulus set could reliably identify AI type III cells, we examined gene expression in these cells using single-cell RT-PCR (Fig. $1 F)$. Six cells physiologically identified as type III AI salt-responsive taste cells based on significant responses to $250 \mathrm{~mm} \mathrm{NaCl}$, $250 \mathrm{~mm} \mathrm{NaCl}$ plus $100 \mu \mathrm{M}$ amiloride, and $50 \mathrm{~mm} \mathrm{KCl}$ were collected and assayed for expression of taste cell marker genes. In agreement with the physiological data, expression for type III marker genes PKD2L1, NCAM, and SNAP25 (Takeda et al., 1992; Nelson and Finger, 1993; Yee et al., 2001; Yang et al., 2004; DeFazio et al., 2006; Huang et al., 2006) was detected in all or most of the collected cells. Note that single-cell RT-PCR is prone to false negatives (Eberwine and Bartfai, 2011) because of the extremely small amount of mRNA present in a single cell. Importantly, expression of the type II cell marker PLC 32 (Clapp et al., 2004; DeFazio et al., 2006) and type I cell marker glutamate-aspartate transporter (GLAST; Lawton et al., 2000) was not detected in any of the physiologically identified AI type III cells.

\section{AI salt responses occur in a subset of acid-responsive type III taste cells}

Multiple lines of evidence have shown that type III cells transduce both AI salt responses and sour responses (Huang et al., 2006; Huang et al., 2008; Tomchik et al., 2007; Yoshida et al., 2009a; Oka et al., 2013). However, no studies have yet resolved whether the salty and sour responses observed in type III taste cells arise from two distinct populations of cells or whether receptors for sour and salty taste are coexpressed in the same type III cells. Much of the difficulty in resolving this question arises from the prevalence of cell-to-cell communication in the intact taste bud, which makes it difficult to determine whether the response of a taste cell to a tastant is attributable to the tastant interacting with receptors/channels expressed by the cell itself or whether the cell is being activated indirectly through cell-to-cell communication (Caicedo et al., 2002; Tomchik et al., 2007; Huang et al., 2009; Roper, 2013). This difficulty is of particular concern for type III taste cells, which commonly respond to multiple taste qualities, including sweet, bitter, and umami (Tomchik et al., 2007), de- 
A

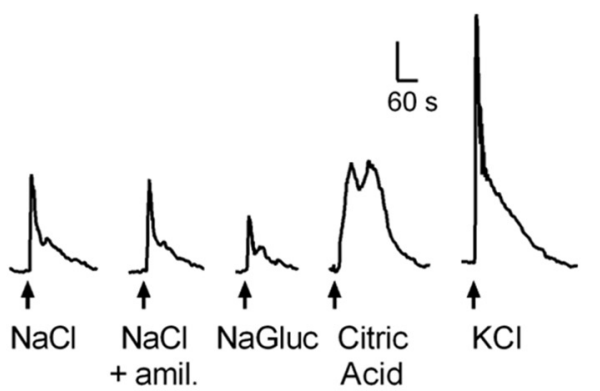

C

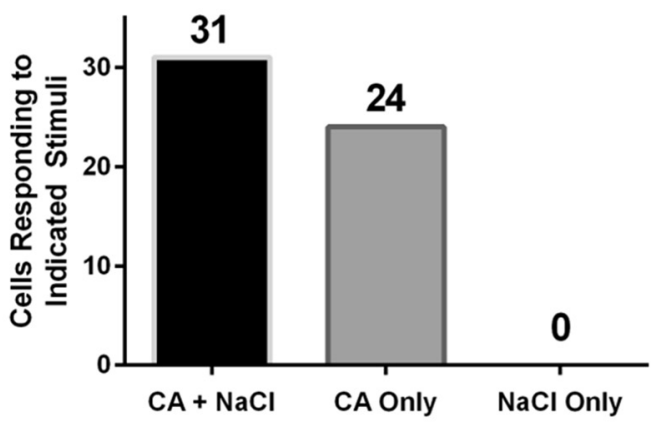

B

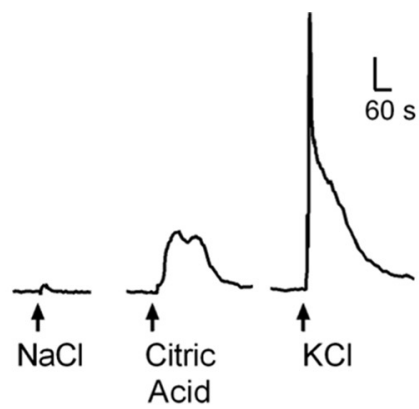

D

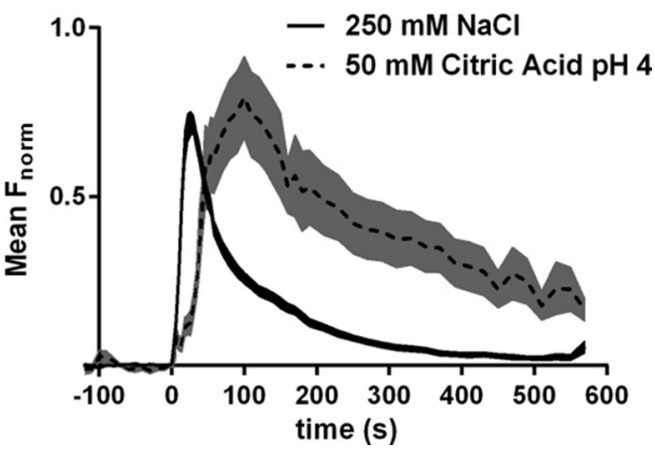

Figure 2. C $\quad \mathrm{Ca}^{2+}$ imaging of isolated taste cells finds that Al salt-responsive type III cells are a subset of sour-responsive type III cells. $A$, An example of an isolated taste cell that responded to a sour stimulus and gave an Al response to salt stimuli. This cell exhibited Ca ${ }^{2+}$ transients in response to $250 \mathrm{~mm} \mathrm{NaCl}, 250 \mathrm{~mm} \mathrm{NaCl}$ plus $100 \mu$ mamiloride, $250 \mathrm{~mm} \mathrm{Na-gluconate} \mathrm{(NaGluc),50} \mathrm{mm} \mathrm{citric} \mathrm{acid,}$ $\mathrm{pH}$ 4, and depolarization with $50 \mathrm{~mm} \mathrm{KCl}$. B. An example of an isolated sour-only responsive type III taste cell responding with $\mathrm{Ca}^{2+}$ transients to citric acid and $\mathrm{KCl}$ depolarization but not to NaCl (concentrations same as in $\boldsymbol{A}$ ). The slight increase in signal after $\mathrm{NaCl}$ presentation results from differences in the diffraction index of the bath solution and the stimulus, which causes a small loss-of-focus artifact that is mostly, but not entirely, compensated for by the ratiometric properties of the fura- $2 \mathrm{Ca}^{2+}$ imaging dye. $A, B$, Black arrows indicate time of stimulus presentation. Vertical scale bars: $0.1 F_{340 \mathrm{~nm} / 380 \mathrm{~nm}}$. C, Bar plot representation of the number of isolated taste cells that responded to both $\mathrm{NaCl}$ and citric acid (CA), responded to citric acid but not NaCl, and responded to $\mathrm{NaCl}$ but not citric acid. D, Mean normalized responses to $250 \mathrm{~mm} \mathrm{NaCl}$ and $50 \mathrm{~mm}$ citric acid, pH 4, across all Al type III cells tested for citric acid responses. Each individual response was aligned with stimulus onset as time 0 and then scaled between 0 (average baseline signal) and 1 (peak response magnitude; for details, see Materials and Methods). Shaded areas around each curve represent \pm SEM (black shading for $\mathrm{NaCl}$, gray for citric acid).

spite not expressing receptors for those taste qualities (Adler et al., 2000; Chandrashekar et al., 2000; Matsunami et al., 2000; Nelson et al., 2001, 2002; Li et al., 2002; Zhang et al., 2003). To resolve the uncertainties regarding the distribution of sour and salty taste responses in type III taste cells, we removed the confounds caused by cell-to-cell communication by measuring taste responses in isolated taste cells.

Isolated taste cells were tested for responses to $\mathrm{NaCl}(250 \mathrm{~mm})$, citric acid (50 mM, pH 4), and $\mathrm{KCl}(50 \mathrm{~mm})$ and/or $\mathrm{NaCl}$ (250 $\mathrm{mm}$ ) plus $100 \mu \mathrm{M}$ amiloride (Fig. 2). The total number of stimuli used to identify AI type III taste cells was reduced in these experiments. AI type III taste cells were identified based on responses to $\mathrm{NaCl}$ and $\mathrm{NaCl}$ plus amiloride $(n=23), \mathrm{NaCl}$ and $\mathrm{KCl}(n=3)$, or $\mathrm{NaCl}, \mathrm{NaCl}$ plus amiloride, and $\mathrm{KCl}(n=5)$. All 31 AI type III taste cells responded robustly to citric acid (AI type III cells, 31 of 55 cells; Fig. 2A). An additional 24 cells responded to citric acid and $\mathrm{KCl}$ depolarization but not to $\mathrm{NaCl}$ (sour-only type III cells, 24 of 55 cells; Fig. 2B). No cells were observed that responded to $\mathrm{NaCl}$ but not to citric acid, indicating that AI salt responses are found in a subset of sour-responsive taste cells (Fig. 2C). All taste cells that responded to citric acid also responded to $\mathrm{KCl}$ depolarization when tested. Note that the sour-only population of taste cells is almost certainly underrepresented in this dataset because the presence of a NaCl-responsive cell was used frequently as a criterion for selecting a recording site. However, this bias would only strengthen the conclusion that AI salt responses appear to be restricted to a subpopulation of sour-responsive type III cells. A small number of cells were also tested for responses to 5 and/or 10 $\mathrm{mm}$ citric acid, $\mathrm{pH}$ 4. Both $\mathrm{NaCl}$-responsive taste cells $(n=4)$ and sour-only taste cells $(n=7)$ gave robust responses to these lower concentrations of citric acid (data not shown). Given that previous studies have demonstrated that sour responses are restricted to type III taste cells (Zhang et al., 2003; Huang et al., 2006, 2008; Oka et al., 2013), the fact that all $\mathrm{NaCl}$-responsive cells in these experiments also responded to citric acid when tested provides additional support that the $\mathrm{NaCl}$-responsive taste cells identified in these and subsequent experiments are type III taste cells. Furthermore, the presence of both sour and AI salty responses in the same type III taste cells fits well with results from previous studies showing that AI salt responses are generally carried by acid/electrolyte generalist E-type neurons in gustatory nerves (Frank et al., 2008).

The onset and time course of citric acid responses were distinctly different from $\mathrm{NaCl}$ and $\mathrm{KCl}$ responses (Fig. 2D). Both time-to-peak response ( $29 \pm 1.4 \mathrm{~s} \mathrm{NaCl} ; 143.2 \pm 19.5 \mathrm{~s}$ citric acid; two-sample Student's $t$ test, $p=3.5 \mathrm{E}-06)$ and response duration $(251.1 \pm 13.2 \mathrm{~s} \mathrm{NaCl} ; 425.3 \pm 55.5 \mathrm{~s}$ citric acid; two-sample Student's $t$ test, $p=0.0083$ ) were significantly longer for citric acid than for $\mathrm{NaCl}$. $\mathrm{NaCl}$ responses in these taste cells were characterized by fast onsets with sharp peaks, while citric acid responses were characterized by slower onsets and a gradual rise to peak response. These response durations are longer than those observed in intact taste buds (Richter et al., 2003; Chandrashekar et al., 2010; Oka et al., 2013), most likely because of the absence of negative feedback pathways and support cells (Roper, 2013). The double peak in citric acid responses that can be seen in Figure 2, $A$ and $B$, was observed occasionally, but a single broad peak was more common, as suggested by the average citric acid response 
curve (Fig. 2D). The observed differences in the shape and time course of salt and sour responses suggest that at least the initial steps of the transduction pathways for salty and sour taste in type III cells are different. This would be one of the first observations in mammals of separate transduction pathways for two different taste qualities coexpressed in the same taste cell. In Drosophila, fatty acid responses may co-occur with sweet and/or umami responses in some taste cells and use separate transduction pathways (Masek and Keene, 2013). Bitter and AI salt responses reported in type II cells appear to use the same G-proteincoupled receptor-based transduction pathway (Oka et al., 2013), as do the sweet and umami responses reported recently in individual taste cells (Kusuhara et al., 2013).

\section{Isolated AI taste cells can exhibit the anion effect}

In the AI salt taste pathway, the magnitude of recorded responses to sodium salts is inversely proportional to the size of the anion of the salt. This anion effect has been hypothesized to result from inhibitory TPs generated by accumulation of less permeable anions at the tight junctions of taste buds (Elliott and Simon, 1990; Ye et al., 1991, 1993). A major goal of these experiments was to test directly the importance of TPs and, more generally, the structure of the intact taste bud, for generating the anion effect. We removed any potential influence of TPs by measuring responses to sodium salts in isolated AI type III taste cells. If the structure of the intact taste bud is necessary for the anion effect, then isolated AI type III taste cells should respond equally well to different sodium salts regardless of their associated anion.

We tested for the presence of the anion effect in isolated AI type III cells by comparing calcium responses to $250 \mathrm{~mm} \mathrm{NaCl}$ (a small-anion sodium salt) and $250 \mathrm{~mm} \mathrm{Na-gluconate} \mathrm{(a} \mathrm{large-}$ anion sodium salt known to induce a robust anion effect; Ye et al., 1991). The majority of isolated AI type III taste cells (38 of 58 cells, 66\%) had calcium responses to $\mathrm{Na}$-gluconate that were $<70 \%$ the magnitude of responses to $\mathrm{NaCl}$ (Figs. $2 A, 3 A$ ). It is clear from these data that isolated taste cells are capable of exhibiting the anion effect. This indicates that at least part of the reduced response to salts with larger anions observed in the AI salt taste pathway can be attributed to the transduction mechanism itself.

A significant fraction of the cells tested (20 of 58, 34\%) did not appear to exhibit the anion effect (Fig. 3B). To enable comparisons across cells, the calcium responses of each cell were normalized to its average $250 \mathrm{~mm} \mathrm{NaCl}$ response. A comparison of the relative magnitude of $\mathrm{Na}$-gluconate responses across cells appeared to show a bimodal distribution, suggesting that AI type III taste cells may be divided into two functional groups based on whether or not they exhibit the anion effect (Fig. $3 C$ ). To test this, we fit the distribution of normalized Na-gluconate responses with a unimodal model (mean $\pm \mathrm{SD}, 0.62 \pm 0.31$ ) and found that it deviated significantly from a theoretical normal distribution $(p<0.02$, Kolmogorov-Smirnov test). A model using two normal distributions to describe the data (a bimodal normal model with mean \pm SD of $0.42 \pm 0.14$ for the first distribution and $0.98 \pm 0.18$ for the second distribution) was a significantly better fit to the experimental data than the unimodal normal model ( $p=0.016, \chi^{2}$ test; see Materials and Methods).

To test whether differences in anion sensitivity correlated with differences in responses to other stimuli, we divided AI type III cells into two groups based on the distribution of responses in Figure 3C: cells with an anion effect (AE + cells, normalized $\mathrm{Na}$-gluconate response $<0.7)$ and cells without an anion effect (AE- cells, normalized Na-gluconate response $>0.7$ ). Given that the AS salt taste pathway does not exhibit an anion effect (Rehnberg et al., 1993; Ye et al., 1993; Breza and Contreras, 2012), we wanted to test whether previous analyses combining $\mathrm{AE}+$ and $\mathrm{AE}$ - cells may have masked some small level of amiloride sensitivity in $\mathrm{AE}-$ cells. A comparison of responses to $\mathrm{NaCl}$ plus amiloride in AE + versus AE - cells (Fig. 3D) revealed no indications of amiloride sensitivity in either group (normalized response, $0.91 \pm 0.04 \mathrm{AE}+$ cells, $n=25 ; 0.92 \pm 0.07 \mathrm{AE}-$ cells, $n=$ 11 ; two-sample Student's $t$ test, $p=0.96$ ). We also tested whether $\mathrm{K}$-gluconate would elicit an anion effect in isolated taste cells. $\mathrm{K}^{+}$ salts directly depolarize isolated taste cells by reversing the electrochemical gradient for $\mathrm{K}^{+}$. Thus, $\mathrm{KCl}$ and $\mathrm{K}$-gluconate would be expected to depolarize isolated taste cells without requiring activation of the AI salt receptor. If isolated taste cells exhibited reduced responses to $\mathrm{K}$-gluconate relative to $\mathrm{KCl}$, it would suggest that larger anions are actively inhibiting the voltage-gated calcium channels involved in AI salt responses (Medler et al., 2003; DeFazio et al., 2006; Roberts et al., 2009). A comparison of responses to $50 \mathrm{~mm} \mathrm{KCl}$ and $50 \mathrm{~mm} \mathrm{~K}$-gluconate revealed no differences (normalized responses, $\mathrm{AE}+$ cells, $n=2 ; \mathrm{KCl}, 3.59 \pm$ 0.55 ; K-gluconate, $3.81 \pm 0.69 ; \mathrm{AE}-$ cells, $n=3$; KCl, $3.65 \pm$ 0.56 ; K-gluconate, $3.60 \pm 0.63$ ). These data suggest that direct depolarization bypasses the elements of the AI salt-response transduction cascade that are sensitive to anion size.

We also wanted to test whether the raw magnitude of calcium responses in a cell was associated with whether that cell exhibited the anion effect. Although differences in the raw magnitude of fluorescent responses could be associated with nonphysiological variables, such as batch-to-batch variability in the solutions used or variability in fluorescent dye loading, it is also possible that these differences are tied to physiological properties of the cells themselves. There is also the practical concern that smallmagnitude responses to $\mathrm{NaCl}$ could interfere with our ability to detect a decrease in response to Na-gluconate. The average raw magnitude of $250 \mathrm{~mm} \mathrm{NaCl}$ responses in $\mathrm{AE}+$ cells $(0.181 \pm$ $\left.0.028 \Delta F_{340 \mathrm{~nm} / 380 \mathrm{~nm}}, n=38\right)$ tended to be higher than in AEcells $\left(0.120 \pm 0.015 \Delta F_{340 \mathrm{~nm} / 380 \mathrm{~nm}}, n=20\right)$, but this difference did not reach significance (two-sample Student's $t$ test, $p=0.06$ ). The average $250 \mathrm{~mm} \mathrm{NaCl}$ response value for $\mathrm{AE}+$ cells is somewhat inflated by three cells that gave unusually large responses (Fig. $4 A$ includes data from one of these cells). There was significant overlap in the distribution of $250 \mathrm{~mm} \mathrm{NaCl}$ response magnitudes in $\mathrm{AE}+$ and $\mathrm{AE}$ - cells; of the 10 cells with the smallest magnitude responses to $250 \mathrm{mM} \mathrm{NaCl}$, six were $\mathrm{AE}+$ and four were AE- cells. Most importantly, despite a tendency towards larger average raw responses to $250 \mathrm{~mm} \mathrm{NaCl}$ in $\mathrm{AE}+$ cells, the average raw response to $250 \mathrm{~mm} \mathrm{Na}$-gluconate was significantly lower in AE + cells $\left(0.073 \pm 0.011 \Delta F_{340 \mathrm{~nm} / 380 \mathrm{~nm}}, n=38\right)$ than in AE - cells $\left(0.120 \pm 0.016 \Delta F_{340 \mathrm{~nm} / 380 \mathrm{~nm}}, n=20 ; p=0.02\right.$, twosample Student's $t$ test). This demonstrates that the raw magnitude of responses to $250 \mathrm{~mm} \mathrm{NaCl}$ in $\mathrm{AE}$ - cells would not impede our ability to detect an anion effect in these cells.

We also compared the time course of $\mathrm{NaCl}$ and $\mathrm{Na}$-gluconate responses in $\mathrm{AE}+$ and $\mathrm{AE}-$ cells. In $\mathrm{AE}+$ cells (Fig. $3 E$ ), intracellular calcium levels increased at a similar rate during $\mathrm{NaCl}$ and $\mathrm{Na}$-gluconate responses. The smaller magnitude of $\mathrm{Na}$-gluconate responses in $\mathrm{AE}+$ cells appeared to result from the rising phase peaking at a significantly earlier time than is seen for $\mathrm{NaCl}$ responses (time-to-peak, $17.8 \pm 1.5 \mathrm{~s} \mathrm{Na-gluconate;} 28.5 \pm 1.7 \mathrm{~s}$ $\mathrm{NaCl}$; paired Student's $t$ test, $p=9.0 \mathrm{E}-06$ ). Interestingly, in $\mathrm{AE}-$ cells, the time-to-peak response was also significantly faster for $\mathrm{Na}$-gluconate than for $\mathrm{NaCl}$ (Fig. 3F; time-to-peak, $20.2 \pm 1.6 \mathrm{~s}$ Na-gluconate; $29.8 \pm 2.4 \mathrm{~s} \mathrm{NaCl}$; paired Student's $t$ test, $p=$ 
A

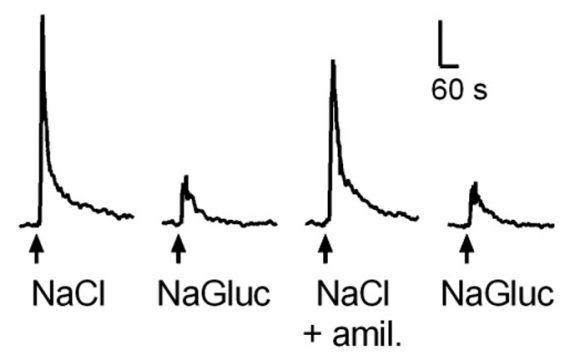

C

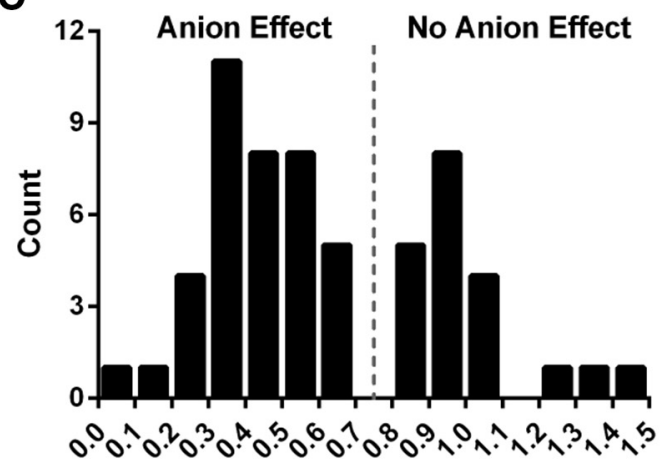

Normalized NaGluconate Response

E

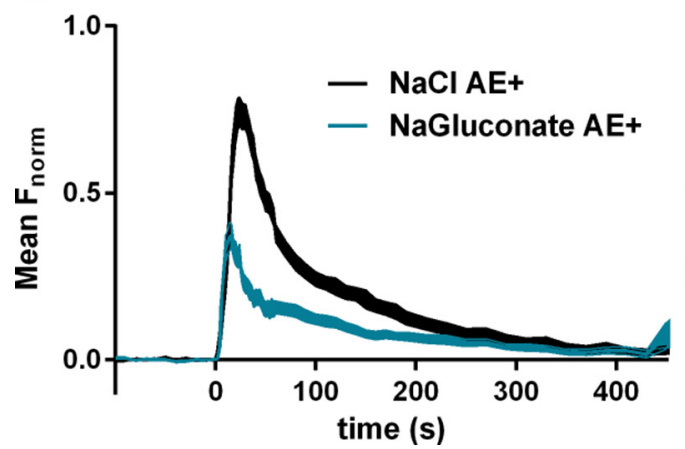

B

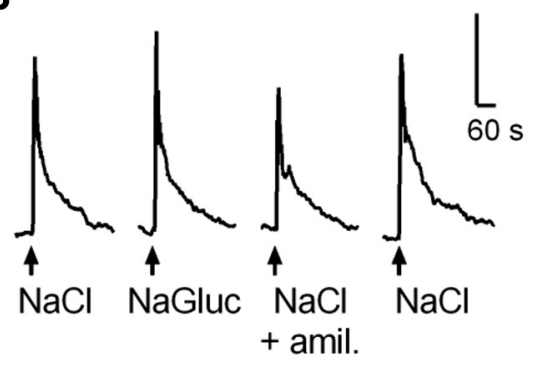

D

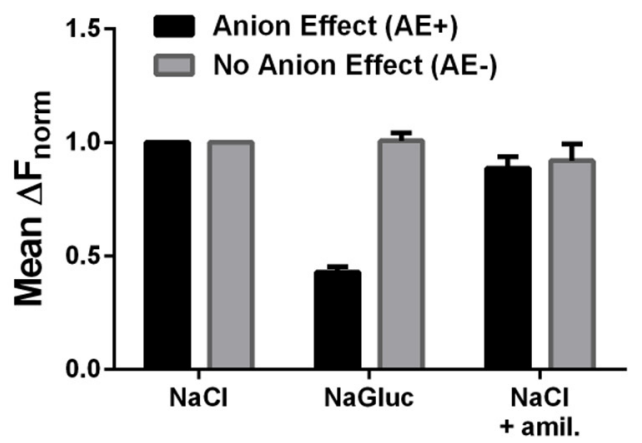

$\mathbf{F}$

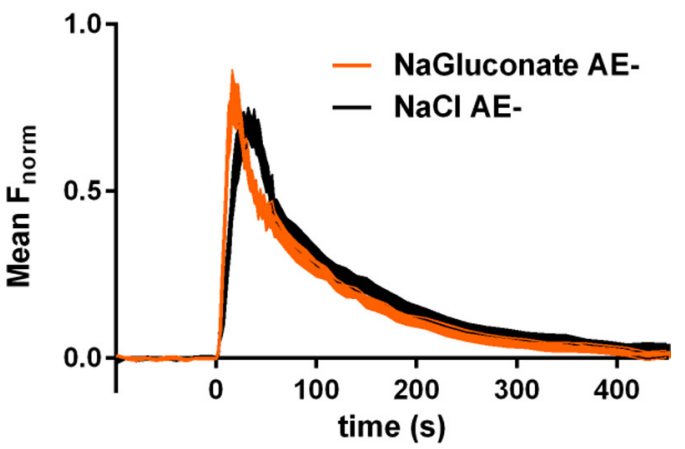

Figure 3. $\mathrm{Ca}^{2+}$ responses in isolated taste cells to salt stimuli identify two classes of Al salt-responsive type Ill taste cells distinguished by their anion sensitivity. $A$, Example data from an isolated taste cell that exhibited the anion effect. Responses to $250 \mathrm{~mm} \mathrm{Na-gluconate} \mathrm{(NaGluc)} \mathrm{were} \mathrm{consistently} \mathrm{smaller} \mathrm{than} \mathrm{responses} \mathrm{to} 250 \mathrm{~mm} \mathrm{NaCl}$ or $250 \mathrm{~mm} \mathrm{NaCl}$ plus $100 \mu \mathrm{m}$ amiloride. $\boldsymbol{B}$, Example data from an isolated taste cell that did not exhibit the anion effect. The identity of the anion did not affect the magnitude of responses to $250 \mathrm{~mm}$ sodium salt stimuli in this cell. Black arrows indicate time of stimulus presentation. Vertical scale bars: $0.1 F_{340 \mathrm{~nm} / 380 \mathrm{~nm}}$. C, Histogram of the average normalized response of each cell to $250 \mathrm{~mm}$ Na-gluconate reveals a bimodal distribution. The responses of each cell are normalized to the average magnitude of the response of that cell to $250 \mathrm{~mm} \mathrm{NaCl}$. The vertical dotted line indicates the threshold used to divide cells into the AE + and AE groups. D, Average \pm SEM normalized responses to $250 \mathrm{~mm} \mathrm{NaCl}$ plus $100 \mu$ m amiloride do not differ between the AE + and AE - groups of Al type III taste cells (two-sample Student's $t$ test, $p=$ 0.96). Bars for $250 \mathrm{~mm} \mathrm{NaCl}$ responses are presented to aid visualization. $\boldsymbol{E}, \boldsymbol{F}$, Average normalized responses to $250 \mathrm{~mm} \mathrm{NaCl}$ and $250 \mathrm{~mm} \mathrm{Na}$-gluconate in $\mathrm{AE}+$ cells $(\boldsymbol{E})$ and $\mathrm{AE}-$ cells $(\boldsymbol{F} ;$ see $\mathrm{Materials}$ and Methods and Fig. $2 D$ for details on creation of plots). Average response data suggests that, although the magnitude of Na-gluconate responses is smaller in AE + cells, the response kinetics to $\mathrm{NaCl}$ and $\mathrm{Na}$-gluconate are similar. In contrast, response magnitudes to $\mathrm{NaCl}$ and $\mathrm{Na}$-gluconate are similar in $\mathrm{AE}$ - cells, but Na-gluconate responses peak significantly earlier than $\mathrm{NaCl}$ responses (see Results).

0.00013). Although the peak magnitude was similar for $\mathrm{NaCl}$ and $\mathrm{Na}$-gluconate in $\mathrm{AE}$ - cells, the rising phase of Na-gluconate responses was steeper than that of $\mathrm{NaCl}$ responses. It is unclear why $\mathrm{Na}$-gluconate responses have faster kinetics than $\mathrm{NaCl}$ responses in AE - cells and whether a similar difference would be observed in the intact taste bud.

\section{Relationship between osmotic responses and AI}

salt responses

The range of anion sensitivity observed in isolated AI type III taste cells suggests that at least two different pathways, one sensitive to anion size and one insensitive to anion size, are contributing to salt stimulus responses in these cells. Given the wide range of both monovalent and divalent salts reported to activate the AI salt pathway (Kitada, 1995; Kloub et al., 1998), it would not be surprising if multiple transduction mechanisms contributed to AI salty taste responses in type III cells. We hypothesized that one of these transduction mechanisms may involve osmosensing because AI salt responses require relatively high concentrations of salt (compared with the AS salt pathway; Chandrashekar et al., 2010), which, like the $250 \mathrm{~mm}$ salt stimuli used in these experiments, are often hypertonic relative to saliva and thus have the potential to act as both a salty taste stimulus and an osmotic stimulus. Interactions between salt taste responses and osmolarity have been observed in the AS salt pathway, but whether osmolarity has similar effects on AI salt responses remains unclear 
A

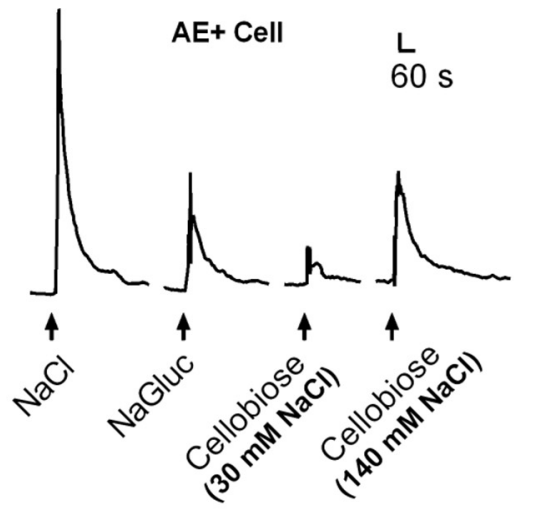

C Anion Effect (AE+)

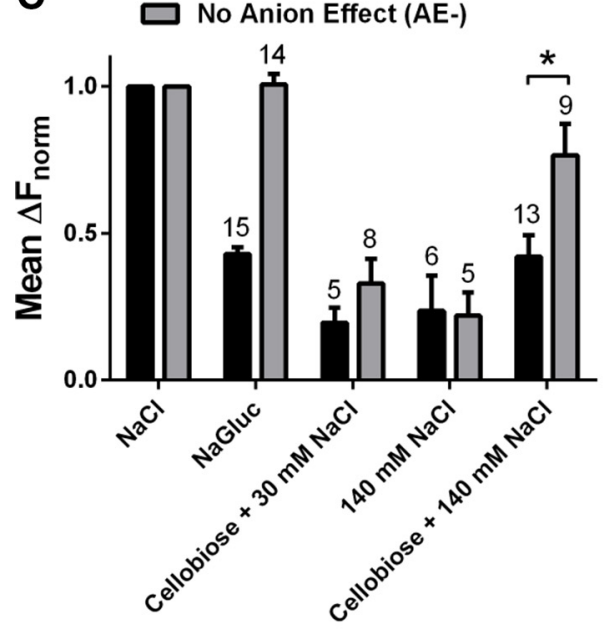

E

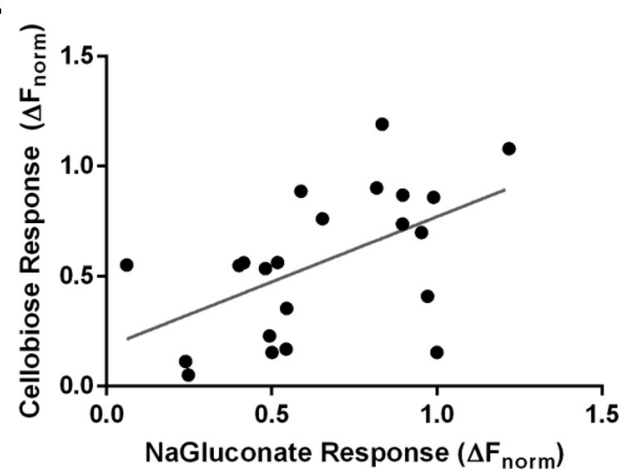

B

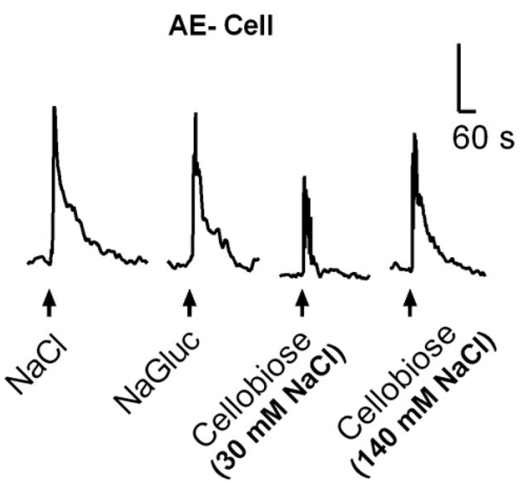

D
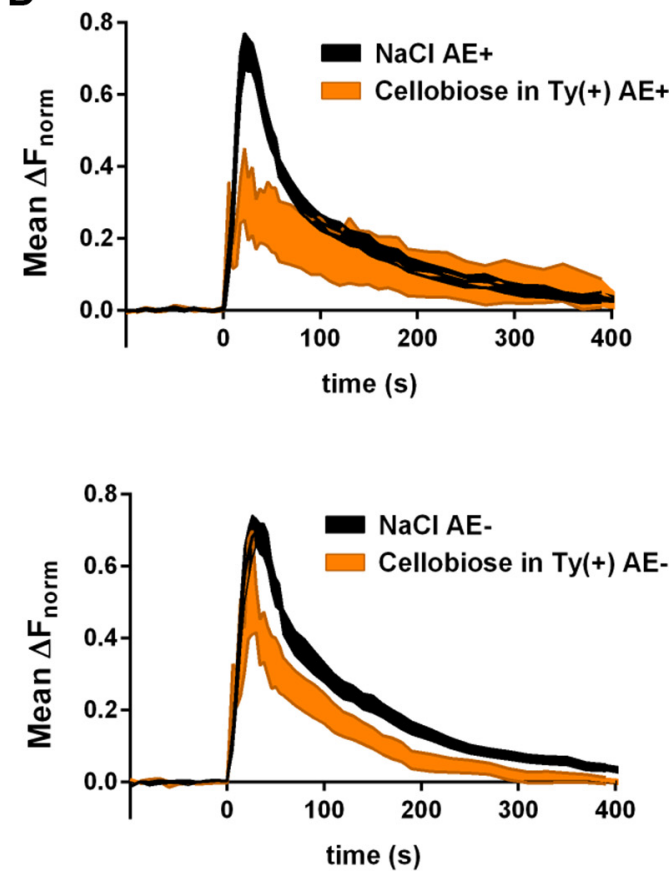

Figure 4. Osmotic responses distinguish AE + and $\mathrm{AE}-$ populations of isolated Al salt-responsive type III taste cells. A, Example calcium imaging data from an isolated AE + Al type III cell showing weak $\mathrm{Ca}^{2+}$ responses to osmotic stimuli. Responses to $220 \mathrm{~mm}$ cellobiose in both a $30 \mathrm{~mm}$ and $140 \mathrm{~mm} \mathrm{NaCl}$ background and $250 \mathrm{~mm} \mathrm{Na-gluconate} \mathrm{(NaGluc)} \mathrm{are} \mathrm{significantly} \mathrm{smaller} \mathrm{than}$ responses to $250 \mathrm{~mm} \mathrm{NaCl}$. B, Example data from an isolated AE - Al type III cell that exhibits strong $\mathrm{Ca}^{2+}$ responses to osmotic stimuli presented in a $140 \mathrm{~mm} \mathrm{NaCl} \mathrm{background} \mathrm{but} \mathrm{weaker} \mathrm{osmotic}$ responses in a low-NaCl $(30 \mathrm{~mm})$ background. Stimuli are the same as $\boldsymbol{A}$. Black arrows indicate time of stimulus presentation. Vertical scale bars: $\boldsymbol{A}, 0.1 F_{340 \mathrm{~nm} / 380 \mathrm{~nm} ;} \boldsymbol{B}, 0.05 F_{340 \mathrm{~nm} / 380 \mathrm{~nm}}$. $\boldsymbol{C}$, Average \pm SEM normalized response magnitudes in $\mathrm{AE}+$ and AE - Al type III taste cells to osmotic stimuli and $140 \mathrm{~mm} \mathrm{NaCl}$. The number of cells tested with each stimulus in this dataset are indicated above the corresponding bar. $\mathrm{Ca}^{2+}$ responses to $220 \mathrm{~mm}$ cellobiose in $30 \mathrm{~mm} \mathrm{NaCl}$ and to $140 \mathrm{~mm} \mathrm{NaCl}$ are small in both AE + and AE - cells and not significantly different ( $p>0.05$; see Results). Responses to $220 \mathrm{~mm}$ cellobiose in a $140 \mathrm{~mm} \mathrm{NaCl}$ background are significantly larger in AE - cells than in AE + cells (two-sample Student's $t$ test, $p=0.017$ ). Response magnitudes to 220 mм cellobiose in a $140 \mathrm{~mm} \mathrm{NaCl}$ background and $250 \mathrm{~mm}$ Na-gluconate were not significantly different for either AE + or AE - cells (two-sample Student's $t$ test, $\mathrm{AE}+$ cells, $p=0.91 ; \mathrm{AE}-$ cells, $p=0.063$ ). Response magnitudes are normalized to $250 \mathrm{~mm} \mathrm{NaCl}$ (bars shown to aid visualization). D. Average normalized responses to $250 \mathrm{~mm} \mathrm{NaCl}$ and $220 \mathrm{~mm}$ cellobiose (140 mu NaCl background) in AE + cells (top) and AE - cells (bottom; see Materials and Methods and Fig. $2 D$ for details on creation of plots). The larger magnitude of osmotic responses in AE - cells can be seen by comparing the average cellobiose response in $\mathrm{AE}+$ and $\mathrm{AE}-$ cells. $\boldsymbol{E}$, Scatter plot comparing the normalized response magnitudes to $220 \mathrm{~mm}$ cellobiose in $140 \mathrm{~mm} \mathrm{NaCl}(\mathrm{Ty}(+))$ and $250 \mathrm{~mm}$ $\mathrm{Na}$-gluconate for both $\mathrm{AE}+$ and $\mathrm{AE}-$ cells. Each data point represents the average normalized response strength in one Al type III taste cell. The magnitude of Na-gluconate responses and osmotic responses is positively correlated (see regression line; $r^{2}=0.2851, p=0.01$ ).

(Lyall et al., 1999). We further hypothesized that the expression of an osmotically sensitive channel that is not sensitive to anion size could explain why some AI type III cells (AE- cells) do not exhibit the anion effect.
To test the osmotic sensitivity of isolated AI type III taste cells, we used the disaccharide cellobiose to create stimuli approximating the osmolarity of the $250 \mathrm{~mm} \mathrm{NaCl}(565 \pm 2 \mathrm{mmol} / \mathrm{kg})$ and $250 \mathrm{~mm} \mathrm{Na}$-gluconate $(568 \pm 4 \mathrm{mmol} / \mathrm{kg}$ ) stimuli (Lyall et al., 
1999). To avoid desensitizing salt-response pathways, the bath solution used for all isolated taste cell experiments was a low$\mathrm{NaCl}$ (30 mM NaCl and $110 \mathrm{~mm}$ NMDG-Cl) version of Tyrode's solution (see Materials and Methods). We first tested osmotic responses using $220 \mathrm{~mm}$ cellobiose dissolved in the low- $\mathrm{NaCl}$ Tyrode's bath solution $(588 \pm 9 \mathrm{mmol} / \mathrm{kg})$. Calcium responses to the osmotic stimulus in this low- $\mathrm{NaCl}(30 \mathrm{~mm})$ background were very weak in both $\mathrm{AE}+(n=5)$ and $\mathrm{AE}-(n=8)$ cells and did not differ significantly between these two cell populations (Fig. 4A-C; two-sample Student's $t$ test, $p=0.20$ ). Although information on the mechanisms underlying hyperosmotic responses is limited, many osmotic responses are mediated by ion channels (Ciura and Bourque, 2006; Sharif Naeini et al., 2006; Ciura et al., 2011; Jin et al., 2011). To maintain ionic balance in our low-NaCl Tyrode's bath solution, we used an equimolar substitution of NMDG-Cl for $\mathrm{NaCl} . \mathrm{NMDG}^{+}$is a large and relatively inert cation that is incapable of passing through most ion channels. Therefore, we hypothesized that a lack of suitable cations (i.e., $\mathrm{Na}^{+}$) could explain the weak osmotic responses we observed in the low- $\mathrm{NaCl}$ (30 mM) background. To test this, we created an osmotic stimulus in a higher $\mathrm{NaCl}$ background by dissolving $220 \mathrm{~mm}$ cellobiose in standard Tyrode's solution (140 mm NaCl and 0 mM NMDG$\mathrm{Cl} ; 599 \pm 5 \mathrm{mmol} / \mathrm{kg}$ ). Calcium responses to the osmotic stimulus in this higher $\mathrm{NaCl}$ background were significantly larger than responses to the osmotic stimulus in a low- $\mathrm{NaCl}$ background (cellobiose in $30 \mathrm{~mm} \mathrm{NaCl}$ background vs $140 \mathrm{~mm} \mathrm{NaCl}$ background; two-sample Student's $t$ test: $\mathrm{AE}+$ cells, $p=0.023$; AEcells, $p=0.0059 ; n$ values indicated in Fig. $4 C$ ). To confirm that these responses were osmotic in nature and not simply responses to the increased concentration of $\mathrm{NaCl}$, we also measured responses to $140 \mathrm{~mm} \mathrm{NaCl}$ Tyrode's solution itself. In both $\mathrm{AE}+$ and $\mathrm{AE}$ - cells, responses to $140 \mathrm{~mm} \mathrm{NaCl}$ were weak and significantly smaller than responses to the $140 \mathrm{~mm} \mathrm{NaCl}$ plus osmotic stimulus (AE+ cells, paired Student's $t$ test, $p=0.014, n=6$; AE - cells, two-sample Student's $t$ test, $p=0.0014, n$ values indicated in Fig. 4C). The presence of osmotic responses and their dependence on sodium strongly suggests that AI type III cells express a sodium-conducting, osmotically sensitive ion channel.

Having established that AI type III cells can exhibit strong osmotic responses, we tested our original hypothesis - that osmotic responses could underlie the lack of an anion effect in some AI type III taste cells - by comparing the magnitude of osmotic responses in $\mathrm{AE}+$ and $\mathrm{AE}-$ cells. As predicted, $\mathrm{AI}$ type III cells that do not exhibit anion sensitivity (AE - cells) had significantly larger osmotic responses than $\mathrm{AE}+$ cells $[140 \mathrm{~mm} \mathrm{NaCl}$ plus cellobiose in $\mathrm{AE}+(n=13)$ vs $\mathrm{AE}-(n=9)$ cells, two-sample Student's $t$ test, $p=0.017$; Figure $4 A-C$ ]. The difference between responses of $\mathrm{AE}+$ and $\mathrm{AE}$ - cells to osmotic stimuli is also apparent in their mean response curves (Fig. 4D). A likely explanation for the larger osmotic responses and the lack of an anion effect in $\mathrm{AE}-$ cells is that salt responses in these cells are mediated primarily by a sodium-conducting, osmotically sensitive ion channel. Consistent with this, there is a significant positive correlation between the size of $\mathrm{Na}$-gluconate responses and the size of osmotic responses $\left(r^{2}=0.2851, p=0.01\right.$; Fig. $\left.4 E\right)$, although there are numerous outliers. This variability, at least in part, may be methodological because testing both salt and osmotic responses required exposing isolated taste cells to multiple stimuli that may present challenges to cell health and could have had nonspecific effects on the responsiveness of a cell to repeated stimuli.

While an osmotically sensitive ion channel appears to be a primary contributor to salt responses in $\mathrm{AE}$ - cells, it also likely contributes, to a lesser degree, to the overall response to salts in
$\mathrm{AE}+$ cells, given that responses to $140 \mathrm{~mm} \mathrm{NaCl}$ plus cellobiose in $\mathrm{AE}+$ cells were significantly larger than responses to $140 \mathrm{~mm}$ $\mathrm{NaCl}$ alone. However, an osmotically sensitive ion channel would not be sufficient to fully explain salt responses in $\mathrm{AE}+$ cells, given their anion sensitivity and their significantly smaller responses to osmotic stimuli than to $\mathrm{NaCl}$. Interestingly, in $\mathrm{AE}+$ cells, the average response magnitude to $\mathrm{Na}$-gluconate and to cellobiose in the $140 \mathrm{~mm} \mathrm{NaCl}$ background was not significantly different (two-sample Student's $t$ test, $p=0.91, n$ values indicated in Fig. $4 C$ ), which could indicate that large anions cause a near complete inhibition of the non-osmotic component of salt responses in $\mathrm{AE}+$ cells. Whether the osmotic responses in $\mathrm{AE}+$ and $\mathrm{AE}-$ cells occur through the same or different mechanisms will require additional investigation.

\section{Discussion}

In mammals, salty taste is specialized for the detection of $\mathrm{NaCl}$ and other salts critical for cellular signaling and homeostasis. Uncovering the mechanisms underlying the detection and palatability of salts, particularly $\mathrm{NaCl}$, may prove important for tackling health problems associated with excessive salt consumption in humans (Yang et al., 2011; Whelton et al., 2012). This study investigated the encoding and transduction of salty taste responses in the AI salt taste pathway.

A major goal of these experiments was to test the hypothesis that the anion effect is caused by inhibitory TPs generated across the taste bud by the differential permeability of tight junctions at the taste pore to cations and anions. We show that, even in the absence of tight junctions and TPs, a majority of AI type III taste cells still exhibit the anion effect, indicating that some component of the AI salt transduction machinery is directly affected by the identity of the anion of a salt.

We also characterized responses in type III taste cells to sour tastants and osmotic stimuli. In the isolated taste cells tested, AI salt responses were restricted to a subpopulation of sourresponsive type III cells. We also found evidence that AI type III taste cells are not a homogeneous population. Among the AI type III cells, a significant minority had strong osmotic responses and did not exhibit the anion effect. These results, in combination with reports of AI salt-like responses in a subpopulation of bitterresponsive type II cells (Oka et al., 2013), suggest that AI salt taste is not transduced by a dedicated population of taste cells.

\section{Characterization of AI salt responses in isolated taste cells}

In the intact taste bud, taste cells are polarized with the majority of their membranes protected from direct exposure to ingested tastants by tight junctions. The basolateral membranes of taste cells are in contact with glial-like support cells and engage in prolific cell-to-cell communication with other taste cells (Roper, 2013). In this study, taste cells were removed from the microenvironment of the taste bud, which necessitates a careful interpretation of the results and their relevance for taste bud function in vivo. One concern is the loss of taste cell polarity, which could potentially enable tastants to interact with receptors that may be inaccessible to them in an intact taste bud. However, there is evidence that $\mathrm{NaCl}$ (Ye et al., 1993, 1994; Anderson and Van Itallie, 2009) and sour taste stimuli (particularly weak acids; Richter et al., 2003) are capable of directly or indirectly bypassing most tight junctions. Thus, there is evidence that the $\mathrm{NaCl}$ and citric acid taste stimuli used in this study could interact with receptors on the basolateral membrane of taste cells even in the intact taste bud. Another concern is that isolated taste cells could exhibit com- 
pletely abnormal responses. The agreement of physiological responses from our isolated cells with recordings from intact taste buds (Tomchik et al., 2007; Oka et al., 2013), combined with the identification of type III cell markers using single-cell RT-PCR, strongly suggests that our data reflect physiologically relevant responses from AI salt-responsive type III taste cells.

\section{The anion effect in isolated taste cells}

In the AI salt taste pathway, the magnitude of recorded responses to sodium and non-sodium salts is inversely proportional to the size of the anion of the salt. Theories proposing that TPs are responsible for this "anion effect" are supported by evidence that salts with larger anions typically generate larger TPs, and direct manipulation of lingual TPs can significantly affect salt-related responses in gustatory nerves (Ye et al., 1991, 1993, 1994). If the anion effect were attributable entirely to inhibitory TPs or some other effect related to the structure of the intact taste bud, then isolated taste cells should respond equally to equimolar concentrations of sodium salts regardless of their associated anion. However, we found that the majority of isolated AI saltresponsive type III taste cells still exhibit reduced responses to $\mathrm{Na}$-gluconate (a large anion sodium salt) compared with $\mathrm{NaCl}$. These findings demonstrate that inhibitory TPs are not necessary for taste cells to exhibit the anion effect; however, they do not preclude the possibility that TPs contribute to the overall magnitude of the anion effect observed in vivo.

In this study, we identified two populations of AI type III taste cells that could be distinguished by whether they did (AE+ cells) or did not (AE - cells) exhibit the anion effect. The AE+ cell population exhibited both the anion effect and $\mathrm{AI} \mathrm{NaCl}$ responses, which fits the expected profile of AI type III taste cells based on gustatory nerve recordings (Frank et al., 2008). There are no specific reports of AI salt-responsive taste cells that do not exhibit the anion effect ( $\mathrm{AE}$ - cells); however, previous studies that looked at salt responses in individual taste cells did not test for the anion effect (Doolin and Gilbertson, 1996; Caicedo et al., 2002; Tomchik et al., 2007; Yoshida et al., 2009a; Chandrashekar et al., 2010; Oka et al., 2013).

The mechanism of AI salt transduction has remained elusive. Our results indicate that some aspect of the transduction mechanism for AI salt taste in type III taste cells is either inhibited by larger anions or else requires smaller anions to function efficiently. The former mechanism may involve the L-type calcium channels expressed by type III cells (Medler et al., 2003; DeFazio et al., 2006; Roberts et al., 2009). Some studies have reported that larger (non- $\mathrm{Cl}^{-}$) anions can significantly reduce the open probability of L-type calcium channels by interacting with the intracellular domain of $\beta$ subunits (Thoreson and Stella, 2000; Babai et al., 2010). However, we did not observe reduced responses to $\mathrm{K}$-gluconate relative to $\mathrm{KCl}$, which would be expected if gluconate was inhibiting calcium channels.

Another possible explanation for the anion effect is that a channel/protein involved in AI salt taste requires smaller anions to function efficiently. Anion exchangers or anionconducting ion channels are membrane proteins that could potentially operate with a level of efficiency approximately correlated with anion size. The $\mathrm{Cl}^{-} / \mathrm{HCO}_{3}^{-}$anion exchanger is notable because its activity is closely tied to the function of carbonic anhydrase (Sterling et al., 2002; Svichar et al., 2009), and inhibition of carbonic anhydrase is one of the only manipulations known to block AI salt responses in type III cells (Oka et al., 2013). However, it is unclear how manipulation of carbonic anhydrase activity could trigger a rapid signal trans- duction cascade. Pharmacological inhibition of anion exchangers had no effect on salt responses (Elliott and Simon, 1990), and inhibition of $\mathrm{Cl}^{-}$channels either had no effect (Elliott and Simon, 1990) or enhanced some salt responses (Miyamoto et al., 2000), although the use of intact and partially intact taste buds in these studies may have prevented inhibition of proteins located on the basolateral surface of taste cells. However, at this time, there is no direct evidence for the involvement of anion exchangers/channels in AI salt transduction.

\section{The encoding of AI salt taste}

Our discovery of a population of type III taste cells that appear to express a $\mathrm{Na}^{+}$-conducting osmotically sensitive ion channel adds another layer of complexity to AI salt taste transduction. Our data suggest that type III taste cells could respond to AI salt stimuli through two separate transduction pathways: (1) an osmotically sensitive pathway; and (2) an anion-inhibitable pathway. Although one pathway appears to predominate in a given AI type III cell, it is not yet clear whether these mechanisms are completely segregated or whether there is some level of coexpression. Furthermore, although taste cells in an intact taste bud can be strongly affected by apically applied osmotic stimuli (Lyall et al., 1999), it is not certain that AE - cells housed in an intact taste bud will exhibit the same osmotically mediated salt response profile we observed in isolated $\mathrm{AE}-$ cells. If $\mathrm{AE}+$ and $\mathrm{AE}-\mathrm{AI}$ type III taste cells can be distinguished in the intact taste bud, then additional research will be needed to determine whether $\mathrm{AE}+$ and $\mathrm{AE}-$ cells are redundant mechanisms for AI salt detection or whether they are complimentary mechanisms for sensing slightly different aspects of the same taste quality.

Previous studies have shown that type III taste cells are critical for both sour and AI salt taste (Huang et al., 2006; Tomchik et al., 2007; Yoshida et al., 2009b; Oka et al., 2013); however, it was unclear whether receptors for these taste qualities were expressed by the same or separate populations of taste cells. By recording from taste cells in the absence of cell-to-cell communication, we were able to show that AI salt responses are found in a subset of sour-responsive taste cells. Combined with previous data showing AI salt taste-like responses in a subset of bitter-sensitive type II cells (Oka et al., 2013), these data would indicate that there is no dedicated population of taste cells underlying AI salt taste. This implies that perception of AI salt taste relies on the combined activation of taste cell populations that also encode other distinct taste qualities (bitter or sour), which is difficult to reconcile with labeled-line theories of taste encoding.

\section{References}

Adler E, Hoon MA, Mueller KL, Chandrashekar J, Ryba NJ, Zuker CS (2000) A novel family of mammalian taste receptors. Cell 100:693-702. CrossRef Medline

Anderson JM, Van Itallie CM (2009) Physiology and function of the tight junction. Cold Spring Harb Perspect Biol 1:a002584. CrossRef Medline

Babai N, Kanevsky N, Dascal N, Rozanski GJ, Singh DP, Fatma N, Thoreson WB (2010) Anion-sensitive regions of L-type CaV1.2 calcium channels expressed in HEK293 cells. PLoS One 5:e8602. CrossRef Medline

Beidler LM (1967) Anion influences on taste receptor response In: Olfaction and taste, Ed II (Hayashi T, ed). New York: Pergamon.

Breza JM, Contreras RJ (2012) Anion size modulates salt taste in rats. J Neurophysiol 107:1632-1648. CrossRef Medline

Caicedo A, Kim KN, Roper SD (2002) Individual mouse taste cells respond to multiple chemical stimuli. J Physiol 544:501-509. CrossRef Medline

Chandrashekar J, Mueller KL, Hoon MA, Adler E, Feng L, Guo W, Zuker CS, Ryba NJ (2000) T2Rs function as bitter taste receptors. Cell 100: 703-711. CrossRef Medline 
Chandrashekar J, Kuhn C, Oka Y, Yarmolinsky DA, Hummler E, Ryba NJ, Zuker CS (2010) The cells and peripheral representation of sodium taste in mice. Nature 464:297-301. CrossRef Medline

Ciura S, Bourque CW (2006) Transient receptor potential vanilloid 1 is required for intrinsic osmoreception in organum vasculosum lamina terminalis neurons and for normal thirst responses to systemic hyperosmolality. J Neurosci 26:9069-9075. CrossRef Medline

Ciura S, Liedtke W, Bourque CW (2011) Hypertonicity sensing in organum vasculosum lamina terminalis neurons: a mechanical process involving TRPV1 but not TRPV4. J Neurosci 31:14669-14676. CrossRef Medline

Clapp TR, Yang R, Stoick CL, Kinnamon SC, Kinnamon JC (2004) Morphologic characterization of rat taste receptor cells that express components of the phospholipase C signaling pathway. J Comp Neurol 468: 311-321. CrossRef Medline

DeFazio RA, Dvoryanchikov G, Maruyama Y, Kim JW, Pereira E, Roper SD, Chaudhari N (2006) Separate populations of receptor cells and presynaptic cells in mouse taste buds. J Neurosci 26:3971-3980. CrossRef Medline

Doolin RE, Gilbertson TA (1996) Distribution and characterization of functional amiloride-sensitive sodium channels in rat tongue. J Gen Physiol 107:545-554. CrossRef Medline

Eberwine J, Bartfai T (2011) Single cell transcriptomics of hypothalamic warm sensitive neurons that control core body temperature and fever response Signaling asymmetry and an extension of chemical neuroanatomy. Pharmacol Ther 129:241-259. CrossRef Medline

Elliott EJ, Simon SA (1990) The anion in salt taste: a possible role for paracellular pathways. Brain Res 535:9-17. CrossRef Medline

Formaker BK, Hill DL (1991) Lack of amiloride sensitivity in SHR and WKY glossopharyngeal taste responses to NaCl. Physiol Behav 50:765-769. CrossRef Medline

Frank ME, Lundy RF Jr, Contreras RJ (2008) Cracking taste codes by tapping into sensory neuron impulse traffic. Prog Neurobiol 86:245-263. CrossRef Medline

Gutierrez RG, Carroll RJ, Wang N, Lee GH, Taylor BH (1995) Analysis of tomato root initiation using a normal mixture distribution. Biometrics 51:1461-1468. CrossRef Medline

Hacker K, Laskowski A, Feng L, Restrepo D, Medler K (2008) Evidence for two populations of bitter responsive taste cells in mice. J Neurophysiol 99:1503-1514. CrossRef Medline

Halpern BP (1998) Amiloride and vertebrate gustatory responses to $\mathrm{NaCl}$. Neurosci Biobehav Rev 23:5-47. CrossRef Medline

Heck GL, Mierson S, DeSimone JA (1984) Salt taste transduction occurs through an amiloride-sensitive sodium transport pathway. Science 223: 403-405. CrossRef Medline

Huang AL, Chen X, Hoon MA, Chandrashekar J, Guo W, Tränkner D, Ryba NJ, Zuker CS (2006) The cells and logic for mammalian sour taste detection. Nature 442:934-938. CrossRef Medline

Huang YA, Maruyama Y, Stimac R, Roper SD (2008) Presynaptic (Type III) cells in mouse taste buds sense sour (acid) taste. J Physiol 586:2903-2912. CrossRef Medline

Huang YA, Dando R, Roper SD (2009) Autocrine and paracrine roles for ATP and serotonin in mouse taste buds. J Neurosci 29:13909-13918. CrossRef Medline

Jin M, Berrout J, O'Neil RG (2011) Regulation of TRP channels by osmomechanical stress. In: TRP channels (Zhu MX, ed). Boca Raton, FL: CRC/ Taylor \& Francis.

Kitada Y (1995) Anions modulate cation-induced responses of single units of the frog glossopharyngeal nerve. Brain Res 694:253-263. CrossRef Medline

Kitada Y, Mitoh Y, Hill DL (1998) Salt taste responses of the IXth nerve in Sprague-Dawley rats: lack of sensitivity to amiloride. Physiol Behav 63: 945-949. CrossRef Medline

Kloub MA, Heck GL, DeSimone JA (1998) Self-inhibition in Ca2+-evoked taste responses: a novel tool for functional dissection of salt taste transduction mechanisms. J Neurophysiol 79:911-921. Medline

Kusuhara Y, Yoshida R, Ohkuri T, Yasumatsu K, Voigt A, Hübner S, Maeda K, Boehm U, Meyerhof W, Ninomiya Y (2013) Taste responses in mice lacking taste receptor subunit T1R1. J Physiol 591:1967-1985. CrossRef Medline

Lawton DM, Furness DN, Lindemann B, Hackney CM (2000) Localization of the glutamate-aspartate transporter, GLAST, in rat taste buds. Eur J Neurosci 12:3163-3171. CrossRef Medline
Li X, Staszewski L, Xu H, Durick K, Zoller M, Adler E (2002) Human receptors for sweet and umami taste. Proc Natl Acad Sci U S A 99:4692-4696. CrossRef Medline

Lyall V, Heck GL, DeSimone JA, Feldman GM (1999) Effects of osmolarity on taste receptor cell size and function. Am J Physiol 277:C800-C813. Medline

Lyall V, Heck GL, Vinnikova AK, Ghosh S, Phan TH, Alam RI, Russell OF, Malik SA, Bigbee JW, DeSimone JA (2004) The mammalian amilorideinsensitive non-specific salt taste receptor is a vanilloid receptor- 1 variant. J Physiol 558:147-159. CrossRef Medline

Masek P, Keene AC (2013) Drosophila fatty acid taste signals through the PLC pathway in sugar-sensing neurons. PLoS Genet 9:e1003710. CrossRef Medline

Matsunami H, Montmayeur JP, Buck LB (2000) A family of candidate taste receptors in human and mouse. Nature 404:601-604. CrossRef Medline

McLachlan GJ (1987) On bootstrapping the likelihood ratio test stastistic for the number of components in a normal mixture. J R Stat Soc C (Appl Stat) 36:318-324.

Medler KF, Margolskee RF, Kinnamon SC (2003) Electrophysiological characterization of voltage-gated currents in defined taste cell types of mice. J Neurosci 23:2608-2617. Medline

Miyamoto T, Fujiyama R, Okada Y, Sato T (2000) Acid and salt responses in mouse taste cells. Prog Neurobiol 62:135-157. CrossRef Medline

Nelson GM, Finger TE (1993) Immunolocalization of different forms of neural cell adhesion molecule (NCAM) in rat taste buds. J Comp Neurol 336:507-516. CrossRef Medline

Nelson G, Hoon MA, Chandrashekar J, Zhang Y, Ryba NJ, Zuker CS (2001) Mammalian sweet taste receptors. Cell 106:381-390. CrossRef Medline

Nelson G, Chandrashekar J, Hoon MA, Feng L, Zhao G, Ryba NJ, Zuker CS (2002) An amino-acid taste receptor. Nature 416:199-202. CrossRef Medline

Ninomiya Y (1998) Reinnervation of cross-regenerated gustatory nerve fibers into amiloride-sensitive and amiloride-insensitive taste receptor cells. Proc Natl Acad Sci U S A 95:5347-5350. CrossRef Medline

Ninomiya Y, Funakoshi M (1988) Amiloride inhibition of responses of rat single chorda tympani fibers to chemical and electrical tongue stimulations. Brain Res 451:319-325. CrossRef Medline

Oka Y, Butnaru M, von Buchholtz L, Ryba NJ, Zuker CS (2013) High salt recruits aversive taste pathways. Nature 494:472-475. CrossRef Medline

Ott J (1992) NOCOM and COMPIX programs. New York: Rockefeller University.

Rehnberg BG, MacKinnon BI, Hettinger TP, Frank ME (1993) Anion modulation of taste responses in sodium-sensitive neurons of the hamster chorda tympani nerve. J Gen Physiol 101:453-465. CrossRef Medline

Richter TA, Caicedo A, Roper SD (2003) Sour taste stimuli evoke Ca2+ and $\mathrm{pH}$ responses in mouse taste cells. J Physiol 547:475-483. CrossRef Medline

Roberts CD, Dvoryanchikov G, Roper SD, Chaudhari N (2009) Interaction between the second messengers cAMP and $\mathrm{Ca} 2+$ in mouse presynaptic taste cells. J Physiol 587:1657-1668. CrossRef Medline

Roper SD (2013) Taste buds as peripheral chemosensory processors. Semin Cell Dev Biol 24:71-79. CrossRef Medline

Roper SD (2015) The taste of table salt. Pflugers Arch 467:457-463. CrossRef Medline

Ruiz C, Gutknecht S, Delay E, Kinnamon S (2006) Detection of $\mathrm{NaCl}$ and $\mathrm{KCl}$ in TRPV1 knockout mice. Chem Senses 31:813-820. CrossRef Medline

Sharif Naeini R, Witty MF, Séguéla P, Bourque CW (2006) An N-terminal variant of Trpvl channel is required for osmosensory transduction. Nat Neurosci 9:93-98. CrossRef Medline

Sterling D, Alvarez BV, Casey JR (2002) The extracellular component of a transport metabolon. Extracellular loop 4 of the human AE1 Cl-/HCO3exchanger binds carbonic anhydrase IV. J Biol Chem 277:25239-25246. CrossRef Medline

Svichar N, Waheed A, Sly WS, Hennings JC, Hübner CA, Chesler M (2009) Carbonic anhydrases CA4 and CA14 both enhance AE3-mediated $\mathrm{Cl}-$ HCO3- exchange in hippocampal neurons. J Neurosci 29:3252-3258. CrossRef Medline

Takeda M, Suzuki Y, Obara N, Nagai Y (1992) Neural cell adhesion molecule of taste buds. J Electron Microsc (Tokyo) 41:375-380. Medline

Thoreson WB, Stella SL (2000) Anion modulation of calcium current volt- 
age dependence and amplitude in salamander rods. Biochim Biophys Acta 1464:142-150. CrossRef Medline

Tomchik SM, Berg S, Kim JW, Chaudhari N, Roper SD (2007) Breadth of tuning and taste coding in mammalian taste buds. J Neurosci 27:1084010848. CrossRef Medline

Treesukosol Y, Lyall V, Heck GL, DeSimone JA, Spector AC (2007) A psychophysical and electrophysiological analysis of salt taste in Trpv1 null mice. Am J Physiol Regul Integr Comp Physiol 292:R1799-R1809. CrossRef Medline

Vandenbeuch A, Clapp TR, Kinnamon SC (2008) Amiloride-sensitive channels in type I fungiform taste cells in mouse. BMC Neurosci 9:1. CrossRef Medline

Whelton PK, Appel LJ, Sacco RL, Anderson CA, Antman EM, Campbell N, Dunbar SB, Frohlich ED, Hall JE, Jessup M, Labarthe DR, MacGregor GA, Sacks FM, Stamler J, Vafiadis DK, Van Horn LV (2012) Sodium, blood pressure, and cardiovascular disease: further evidence supporting the American Heart Association sodium reduction recommendations. Circulation 126:2880-2889. CrossRef Medline

Yang Q, Liu T, Kuklina EV, Flanders WD, Hong Y, Gillespie C, Chang MH, Gwinn M, Dowling N, Khoury MJ, Hu FB (2011) Sodium and potassium intake and mortality among US adults: prospective data from the Third National Health and Nutrition Examination Survey. Arch Intern Med 171:1183-1191. CrossRef Medline

Yang R, Stoick CL, Kinnamon JC (2004) Synaptobrevin-2-like immunoreactivity is associated with vesicles at synapses in rat circumvallate taste buds. J Comp Neurol 471:59-71. CrossRef Medline

Ye Q, Heck GL, DeSimone JA (1991) The anion paradox in sodium taste reception: resolution by voltage-clamp studies. Science $254: 724-726$. CrossRef Medline

Ye Q, Heck GL, DeSimone JA (1993) Voltage dependence of the rat chorda tympani response to $\mathrm{Na}+$ salts: implications for the functional organization of taste receptor cells. J Neurophysiol 70:167-178. Medline

Ye Q, Heck GL, DeSimone JA (1994) Effects of voltage perturbation of the lingual receptive field on chorda tympani responses to $\mathrm{Na}+$ and $\mathrm{K}+$ salts in the rat: implications for gustatory transduction. J Gen Physiol 104: 885-907. CrossRef Medline

Yee CL, Yang R, Böttger B, Finger TE, Kinnamon JC (2001) “Type III” cells of rat taste buds: immunohistochemical and ultrastructural studies of neuron-specific enolase, protein gene product 9.5, and serotonin. J Comp Neurol 440:97-108. CrossRef Medline

Yee KK, Sukumaran SK, Kotha R, Gilbertson TA, Margolskee RF (2011) Glucose transporters and ATP-gated K+ (KATP) metabolic sensors are present in type 1 taste receptor 3 (T1r3)-expressing taste cells. Proc Natl Acad Sci U S A 108:5431-5436. CrossRef Medline

Yoshida R, Horio N, Murata Y, Yasumatsu K, Shigemura N, Ninomiya Y (2009a) $\mathrm{NaCl}$ responsive taste cells in the mouse fungiform taste buds. Neuroscience 159:795-803. CrossRef Medline

Yoshida R, Miyauchi A, Yasuo T, Jyotaki M, Murata Y, Yasumatsu K, Shigemura N, Yanagawa Y, Obata K, Ueno H, Margolskee RF, Ninomiya Y (2009b) Discrimination of taste qualities among mouse fungiform taste bud cells. J Physiol 587:4425-4439. CrossRef Medline

Zhang Y, Hoon MA, Chandrashekar J, Mueller KL, Cook B, Wu D, Zuker CS, Ryba NJ (2003) Coding of sweet, bitter, and umami tastes: different receptor cells sharing similar signaling pathways. Cell 112:293-301. CrossRef Medline 